Proceedings of the 2011 Winter Simulation Conference

S. Jain, R.R. Creasey, J. Himmelspach, K.P. White, and M. Fu, eds.

\title{
ANALYZING TRANSIT TUNNEL CONSTRUCTION STRATEGIES USING DISCRETE EVENT SIMULATION
}

\author{
Elmira Moghani \\ Hala AbouRizk \\ Simaan M. AbouRizk \\ University of Alberta \\ Dept. of Civil \& Environmental Engineering \\ Edmonton, AB T6G 2W2, CANADA
}

\author{
Heiner Sander
}

ILF Consultants, Inc.

3911 Old Lee Highway, Suite 42E

Fairfax, Virginia 22030, USA

\begin{abstract}
Selection of an appropriate construction strategy for a project is one of the challenges faced in the planning stage. It is essential to choose a suitable method that can reduce cost, time, and any disruption in the area, especially for projects in urban areas. The management group must consider possible techniques, test various scenarios using those techniques, calculate the associated cost and time, and determine the most desirable solution. In this research, a simulation based approach was used to assist the management group in choosing the best strategy for construction of a transit tunnel project in Edmonton, Alberta, Canada. A discrete event simulation tool was developed to model a Sequential Excavating method using either shotcrete or rib and lagging as preliminary supporting systems. The tool enables users to create simulation models for different methods and calculate total duration, resource utilization, and cost of the project. The results comparison is demonstrated in this paper.
\end{abstract}

\section{INTRODUCTION}

Selection of a construction strategy among possible alternatives at the beginning of a project is a challenging task which requires analysis of potential scenarios, equipment and material utilization, and human resource allocation to select the best solution, based on estimated cost and total duration of each scenario. A simulation technique can support the decision making process as it enables the modeling of an actual construction process on a computer, and lets managers examine various options, compare their results, and select a desirable solution. In many studies in the construction domain, simulation tools have been used for comparing alternatives. For example, Ioannou and Martinez (1996) used STROBOSCOPE to develop simulation models to compare two construction methods for a tunnel project, the conventional method and the New Austrian Tunneling Method (NATM).

In this project, a simulation approach is applied to compare construction strategies for a transit tunnel project in Edmonton, Alberta, Canada. Based on preliminary studies, the management group has decided that two different construction methods can be implemented in this project: a sequential excavation method with either rib and lagging or shotcrete as primary liners. They also defined different sequences for the excavation process, which created new alternatives to compare.

Simulation models were developed in Simphony.NET 3.5, a simulation tool developed for the construction domain. Simphony is known as a powerful construction simulation tool that provides both general-purpose and special purpose simulation tools and allows users to model construction activities, connect them together, and assign them related resources to represent a real construction process. Simphony provides a graphical user interface; developers can easily modify the process, change the parameters of the model, run the simulation, and get new results. Simphony has been successfully employed in many 


\section{Moghani, AbouRizk, AbouRizk and Sander}

construction management studies, especially in the area of tunnel construction simulation (Mohamed and AbouRizk (2001); Ruwanpura (2001); Fernando et al. (2003); Al-Bataineh, (2008); Marzok et al. (2008))

In this paper, the process of developing simulation models for two construction strategies for the transit tunnel project is discussed in detail, and analysis of simulation outputs and comparison of results is illustrated.

\section{THE NORTH LRT (LIGHT RAIL TRANSIT) TUNNEL PROJECT}

\subsection{Project Description}

The City of Edmonton is constructing a $3.3 \mathrm{~km}$ LRT extension from an existing station (Churchill station) to the northwest of the city. This study focuses on a part of this project: two parallel tunnels with a total length of $764 \mathrm{~m}$, extending from the existing underground station to the street level station (MacEwan station).This is the only portion of the project that will be constructed as an underground tunnel. The construction will start from tunnel portals located at MacEwan station and will be continued up to the prebuilt section. The remaining sections will be constructed from the end of the pre-built section to Churchill station, as shown in Figure 1.

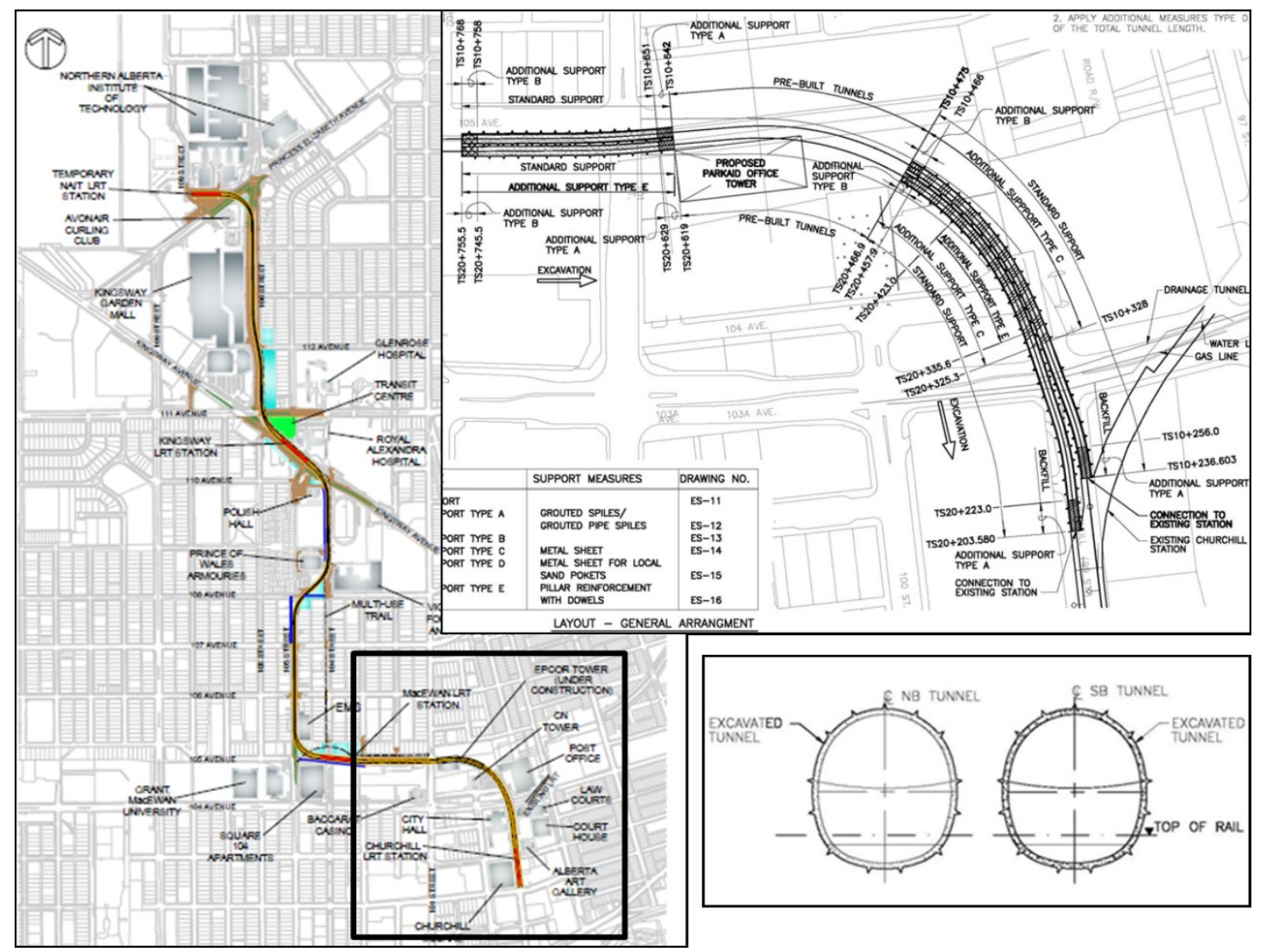

Figure 1: NLRT Project Layout (ILF Consultants, Inc. 2008)

Sequential excavation was selected as the excavation method in both construction strategies under study. In the sequential excavation process, a cross section is divided in smaller segments based on tunnel size; these segments are excavated in sequence for a one meter advancement of the tunnel. In this project, the cross section is divided in heading and bench sections with approximately similar areas, as shown in Figure 2(a). An excavator, a loader and a truck are considered as a set of equipment for excavation and mucking processes. Two assumptions were made for the construction sequence: 


\section{Moghani, AbouRizk, AbouRizk and Sander}

1. Excavation and lining of two one-meter heading sections is followed by the excavation and lining of a two-meter bench section. This process is illustrated in Figure 2(b).

2. Excavation and lining of a one-meter heading for a specific length of the tunnel is followed by the excavation and lining of a bench for the same length.

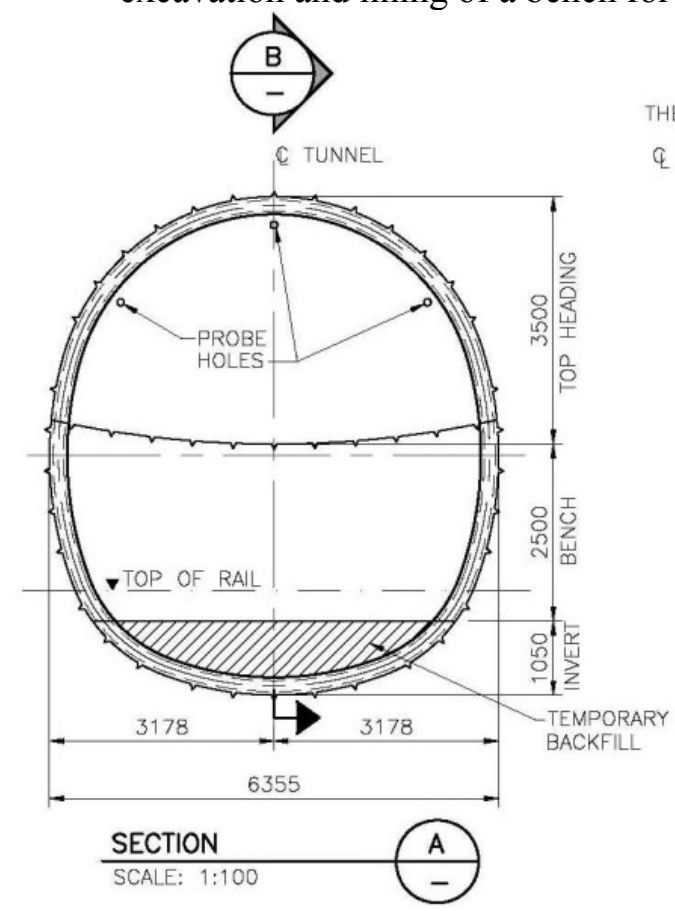

(a)

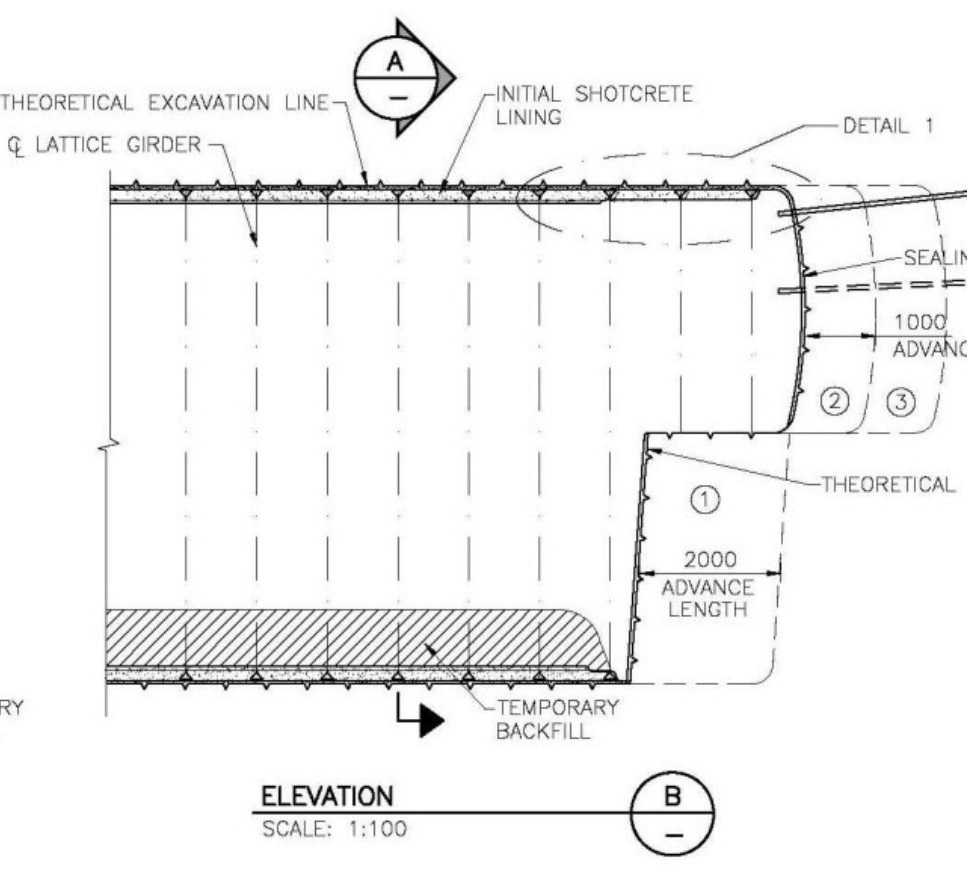

(b)

Figure 2: Tunnel cross section and excavation sequence (IFL Consultants, Inc. 2008)

\subsection{Sequential Excavation with Rib and Lagging Lining System}

With the tunnelling method which uses a rib and lagging lining system, the entire tunnel is lined using the same materials and lining arrangements. The steel ribs are installed every one meter at the end of excavated sections. Laggings, or wooden pieces, are inserted between ribs and soil to support the excavated area. Ribs usually come in one or two sections and are bolted together when they are fixed in their location. A timber spreader and steel rods are used to fix the position of ribs. Based on the tunnel alignment, surveying will be performed every 6-15 meters, and utilities are installed as the tunnel advances.

\subsection{Sequential Excavation with Shotcrete Lining System}

With the shotcrete lining method the preliminary lining differs along the tunnel based on geotechnical condition. The designers for this considered a standard support system for both tunnels which includes installation of different layers of shotcrete and wire mesh. In this project three layers of shotcrete with two layers of wire mesh in between are specified as a standard support.

In addition to the standard support, designers defined five types of additional supports based on soil conditions, and then divided tunnels into longitudinal sections based on their needs for additional supports. All the sections with their additional supports are listed in Table 1. Because for simulation purposes the lengths of each section and the installation durations for the additional supports are the only important factors, the design characteristic of each support will not be discussed in this paper. 
Table 1: Tunnel longitudinal sections based on additional supports for shotcrete lining

\begin{tabular}{|c|c|c|c|c|}
\hline \multicolumn{5}{|c|}{ NLRT - North bound } \\
\hline Section & $\begin{array}{c}\text { Start } \\
\text { point }\end{array}$ & $\begin{array}{c}\text { End } \\
\text { Point }\end{array}$ & Length & $\begin{array}{c}\text { Additional } \\
\text { Supports* }\end{array}$ \\
\hline North1 & 768 & 758 & 10 & B \\
\hline North2 & 758 & 651 & 107 & - \\
\hline North3 & 651 & 642 & 9 & A \\
\hline North4 & 642 & 475 & 167 & Pre-Built \\
\hline North5 & 475 & 466 & 9 & B+C \\
\hline North6 & 466 & 328 & 138 & C \\
\hline North7 & 328 & 256 & 72 & - \\
\hline North8 & 256 & 236.6 & 19.4 & A \\
\hline
\end{tabular}

*All the sections have the standard support

\begin{tabular}{|c|c|c|c|c|}
\hline \multicolumn{5}{|c|}{ NLRT - South bound } \\
\hline Section & $\begin{array}{c}\text { Start } \\
\text { point }\end{array}$ & $\begin{array}{c}\text { End } \\
\text { Point }\end{array}$ & Length & $\begin{array}{c}\text { Additional } \\
\text { Supports* }\end{array}$ \\
\hline South1 & 755.5 & 745.5 & 10 & B+E \\
\hline South2 & 745.5 & 629 & 116.5 & E \\
\hline South3 & 629 & 619 & 10 & A+E \\
\hline South4 & 619 & 466.9 & 152.1 & Pre-Built \\
\hline South5 & 466.9 & 457.9 & 9 & B+C \\
\hline South6 & 457.9 & 423 & 34.9 & C \\
\hline South 7 & 423 & 335.6 & 87.4 & C+E \\
\hline South8 & 335.6 & 325.3 & 10.3 & C \\
\hline South9 & 325.3 & 223 & 102.3 & - \\
\hline South10 & 223 & 203.58 & 19.42 & A \\
\hline
\end{tabular}

*All the sections have the standard support

\section{NLRT TUNNEL CONSTRUCTION SIMULATION IN SIMPHONY}

In this research, simulation models were developed in Simphony.NET 3.5, a Microsoft Windows-based construction simulation tool to model a discrete event simulation systems. This software is the latest version of Simphony, which was originally developed at the University of Alberta (Hajjar and AbouRizk 1999). Simphony provides a framework for developing General Purpose Simulation (GPS) and Special Purpose Simulation (SPS) templates to help users in academia and industry create construction process models, based on their knowledge of simulation as well as the construction domain. Using the GPS template, users build models utilizing abstract elements such as activities, queues, and resources. SPS templates provide a set of elements related to a particular construction domain, which makes simulation more accessible for industry. Simphony has a graphical user interface and hierarchical modeling capability. Users can drag and drop elements into the Simphony modeling interface and connect them based on the logic of a given process. Resources are assigned for different activities in the process and statistical results are available for every resource in the process.

In Simphony, a simulation model can have any number of runs for Monte Carlo simulation purposes if required. More than one scenario can be modeled in one simulation file, which allows a user to run scenarios and compare them at the same time. Simphony includes statistical outputs and different kinds of reports, such as cost and resource utilization, which are useful for comparison purposes.

\subsection{Model Development}

Four different models were created for the NLRT tunnel project using the GPS template in Simphony.NET 3.5, one for each alternative, as listed in Table 2.

Table 2: Tunnel Simulation Model Alternatives

\begin{tabular}{|c|c|l|}
\hline Alternative & Construction method & \multicolumn{1}{c|}{ Excavation process } \\
\hline Alternative 1 & Shotcrete Lining & Excavate Heading and Bench in sequence \\
\hline Alternative 2 & Rib \& Lagging Lining & Excavate Heading and Bench in sequence \\
\hline Alternative 3 & Rib \& Lagging Lining & Excavate Headings (for the entire tunnel), then Bench sections \\
\hline Alternative 4 & Rib \& Lagging Lining & Combination of Alt. 2 and Alt. 3 processes \\
\hline
\end{tabular}

In Alternative 4, because the soil condition of the tunnel in the middle section (Sections with additional support type $\mathrm{C}$ shown in Figure 3) is not good, experts suggested that the excavation of these sections be the same as Alternative 3 and the rest constructed the same as Alternative 2. 


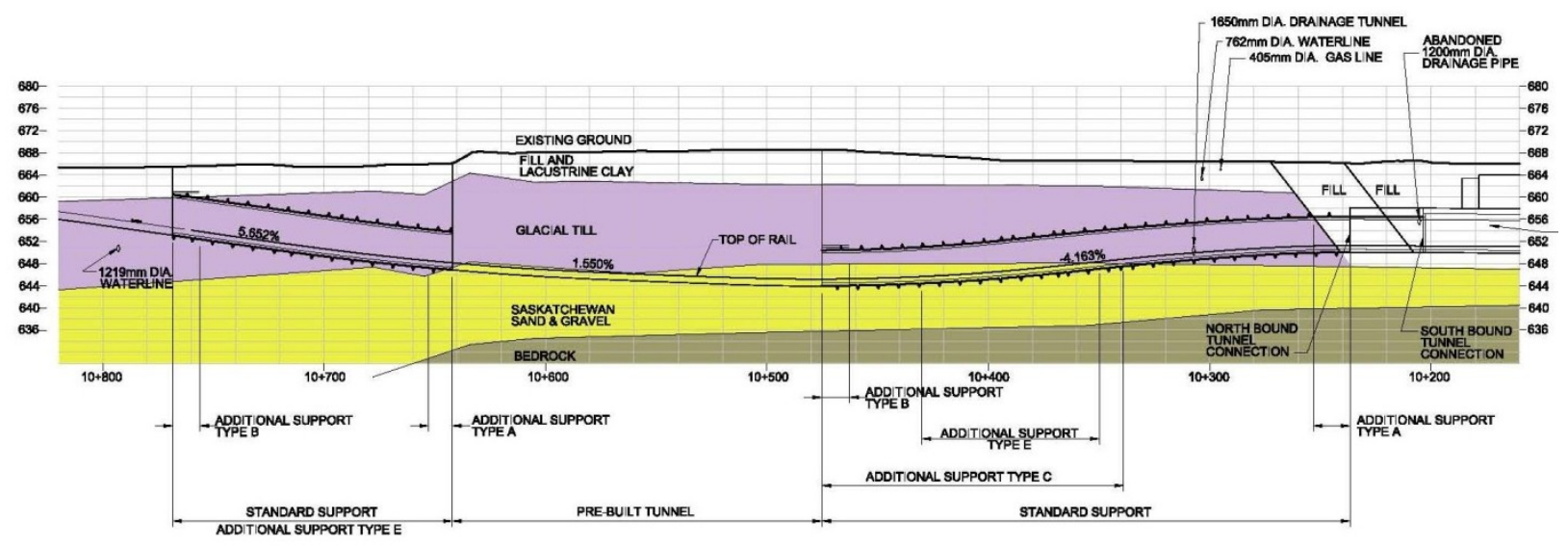

Figure 3: Tunnel Longitudinal Sections (ILF Consultants, Inc. 2008)

The simulation algorithm for Alternative 1 is shown in Figure 4. The same algorithm with a different list of activities for heading and bench construction was considered for the rib and lagging lining in alternative 2 . In alternative 3 , the process is simpler as the construction of headings is completed before construction of bench sections.

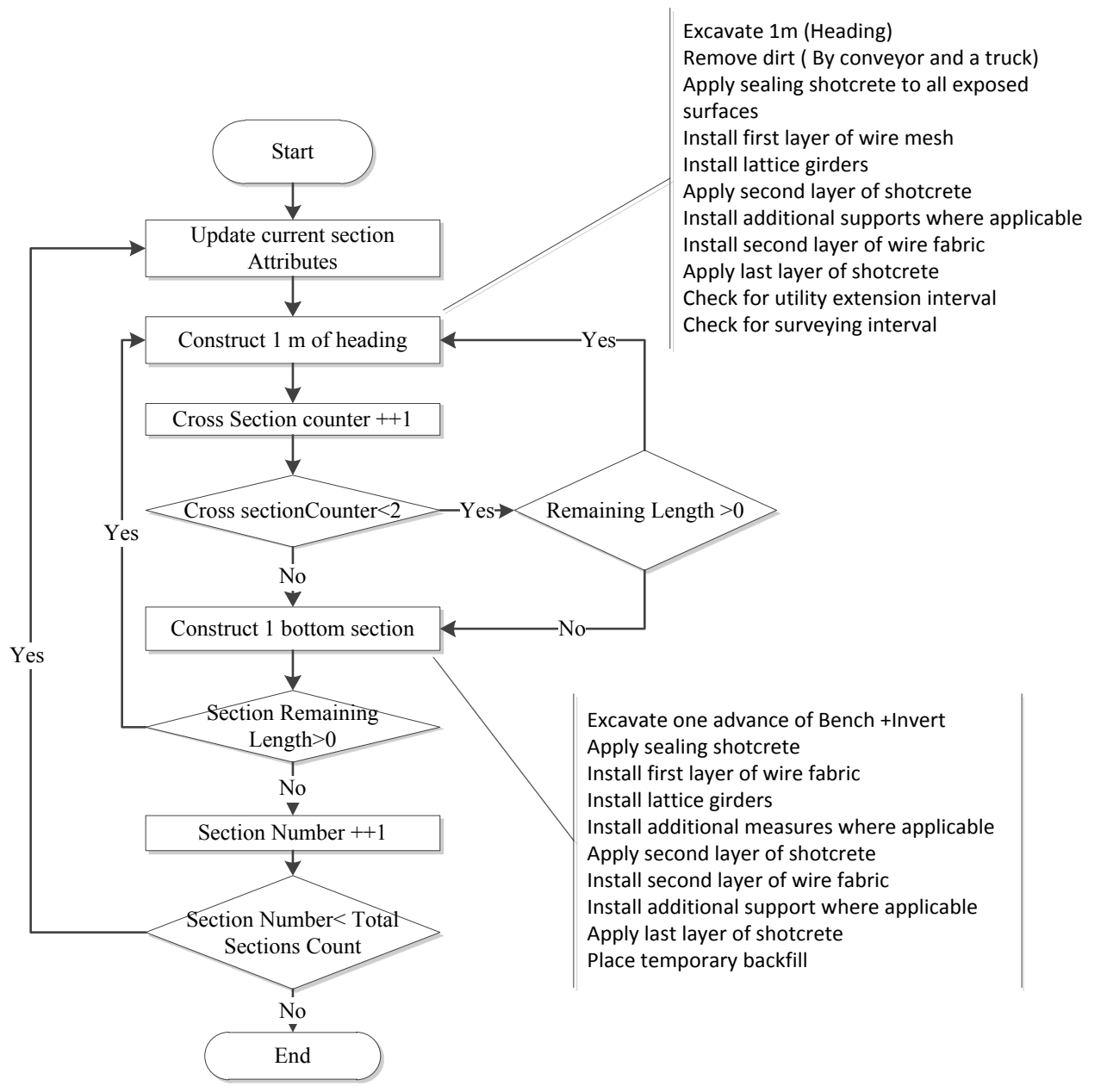

Figure 4: Simulation Process Algorithm 


\section{Moghani, AbouRizk, AbouRizk and Sander}

To create graphically similar models and ease development, the simulation model for the rib and lagging method was created in a similar manner to the shotcrete lining method and also considered the longitudinal sections. This did not affect the simulation process and outputs but resulted in models with similar appearances in the Simphony user interface. Figure 5 shows the simulation model for both construction methods. As it is shown in this figure, in both models the south and north bound tunnels are simulated in the same Simphony file so the limitation of start time for the north bound tunnel can be considered in the model (via a valve element at the beginning of the north bound process model which controls an activator element in the south bound model; when the length of south bound construction reaches $30 \mathrm{~m}$, the activator opens the valve and allows the process in the north bound tunnel to start.)

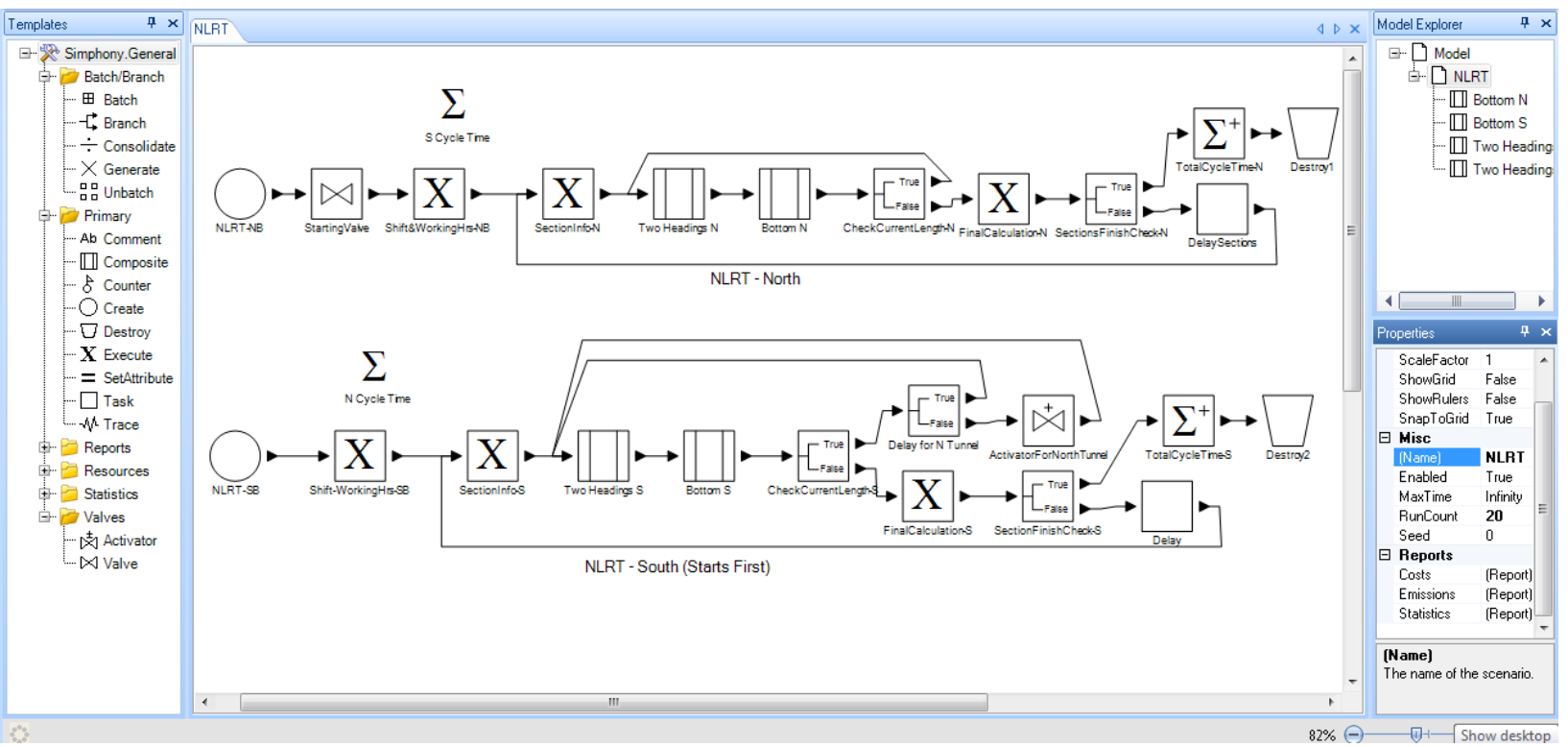

Figure 5: Simulation model for different construction strategies for NLRT project

In order to make the model more organized and understandable for the user, the hierarchical feature of Simphony was used; all activities for the excavation and lining of the heading and bench are encapsulated in two composite elements (i.e., an element that has no simulation behaviour and is used for grouping elements). Inside of each composite element two cycles are modeled; the main cycle simulates the excavation and lining process depending on the type of construction method and the other one simulates the trucking cycle for removing dirt to the outside of the tunnel, which is similar for both methods. Figure 6 shows the process of excavation and lining of one heading.

The sequence of tasks and their duration are obtained from historical data and expert opinion. The durations are presented as minimum, maximum, and most likely values (i.e., a triangular distribution) for each activity. The statistical elements record the duration of each cycle for different simulation runs. 


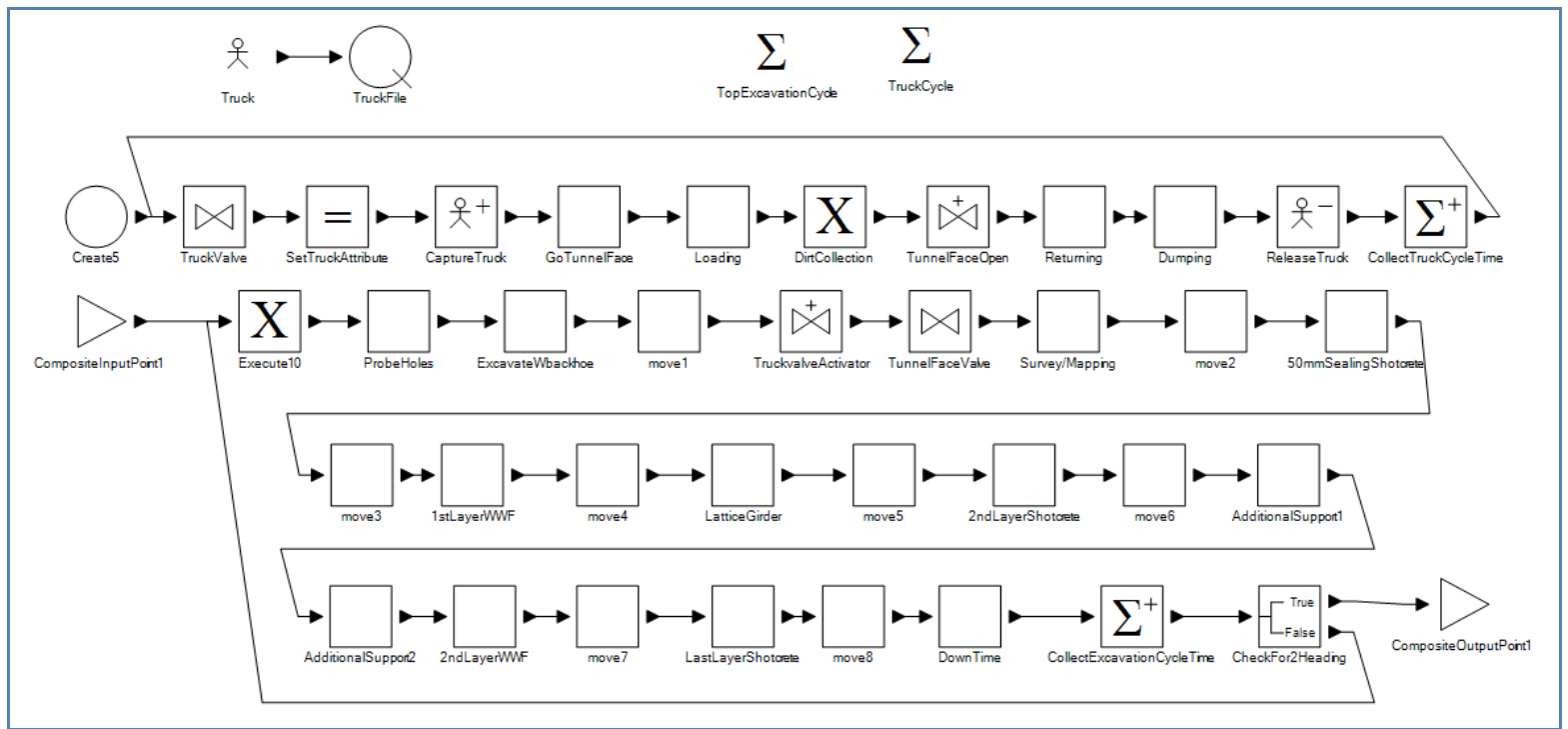

Figure 6: Simulation model for the excavation and lining of one heading section

\section{SIMULATION RESULTS AND ANALYSIS}

Each simulation model was executed for 100 runs, to perform Monte Carlo simulation analysis and to provide users with statistical output such as resource utilization and cycle times. Also, for every simulation model, different scenarios were defined by changing inputs such as resources, shift length, number of shifts per day and number of working days per week. This allows users to test possible situations, compare outputs and select the best solution. As an example, the results for Alternative 1 are included in Table 3 .

Table 3: Simulation result for Alternative 1 - Shotcrete Lining

\begin{tabular}{|c|c|c|c|c|c|c|c|}
\hline & & $\begin{array}{c}\text { Mobilization } \\
(\text { Week) }\end{array}$ & $\begin{array}{c}\text { Shift } \\
\text { Length (H) }\end{array}$ & $\begin{array}{c}\text { Shift Per } \\
\text { Day }\end{array}$ & $\begin{array}{c}\text { Days Per } \\
\text { Week }\end{array}$ & $\begin{array}{c}\text { working } \\
\text { weeks }\end{array}$ & $\begin{array}{c}\text { Total } \\
\text { weeks }\end{array}$ \\
\hline \multirow{2}{*}{ 艺 } & Scenario 1 & 5 & 10 & 2 & 5 & 44 & 53 \\
\cline { 2 - 8 } & Scenario 2 & 5 & 12 & 2 & 5 & 36 & 45 \\
\hline
\end{tabular}

\begin{tabular}{|c|c|c|c|c|c|c|c|}
\hline & & $\begin{array}{c}\text { Mobilization } \\
\text { (Week) }\end{array}$ & $\begin{array}{c}\text { Shift } \\
\text { Length (H) }\end{array}$ & $\begin{array}{c}\text { Shift Per } \\
\text { Day }\end{array}$ & $\begin{array}{c}\text { Days Per } \\
\text { Week }\end{array}$ & $\begin{array}{c}\text { working } \\
\text { weeks }\end{array}$ & $\begin{array}{c}\text { Total } \\
\text { weeks }\end{array}$ \\
\hline \multirow{2}{*}{} & Scenario 1 & 5 & 10 & 2 & 5 & 51 & 66 \\
\cline { 2 - 8 } & Scenario 2 & 5 & 12 & 2 & 5 & 40 & 55 \\
\hline
\end{tabular}

5-week and 11-week mobilization durations were considered for the north bound and south bound portions of the project, respectively. A delay after the pre-built section was also taken into consideration, to transfer equipment and mobilize tunnel parts. The results of simulation models for other alternatives and their associated scenarios are summarized in Table 4. 


\section{Moghani, AbouRizk, AbouRizk and Sander}

Table 4: Simulation Result for Alternative 2 - Rib \& Lagging

\begin{tabular}{|c|c|c|c|c|c|c|c|}
\hline & & $\begin{array}{c}\text { Mobilization } \\
(\text { Week })\end{array}$ & $\begin{array}{c}\text { Shift } \\
\text { Length }(\mathrm{H})\end{array}$ & $\begin{array}{c}\text { Shift Per } \\
\text { Day }\end{array}$ & $\begin{array}{c}\text { Days Per } \\
\text { Week }\end{array}$ & $\begin{array}{c}\text { working } \\
\text { weeks }\end{array}$ & $\begin{array}{c}\text { Total } \\
\text { weeks }\end{array}$ \\
\hline \multirow{2}{*}{ ¿ } & Scenario 1 & 5 & 10 & 2 & 5 & 75 & 84 \\
\cline { 2 - 8 } 乙 & Scenario 2 & 5 & 12 & 2 & 5 & 62 & 71 \\
\hline
\end{tabular}

\begin{tabular}{|c|c|c|c|c|c|c|c|}
\hline & & $\begin{array}{c}\text { Mobilization } \\
\text { (Week) }\end{array}$ & $\begin{array}{c}\text { Shift } \\
\text { Length }(\mathrm{H})\end{array}$ & $\begin{array}{c}\text { Shift Per } \\
\text { Day }\end{array}$ & $\begin{array}{c}\text { Days Per } \\
\text { Week }\end{array}$ & $\begin{array}{c}\text { working } \\
\text { weeks }\end{array}$ & $\begin{array}{c}\text { Total } \\
\text { weeks }\end{array}$ \\
\hline \multirow{2}{*}{$\begin{array}{l} \\
\bar{E} \\
\text { in }\end{array}$} & Scenario 1 & 5 & 10 & 2 & 5 & 80 & 95 \\
\hline & Scenario 2 & 5 & 12 & 2 & 5 & 66 & 81 \\
\hline
\end{tabular}

Two other scenarios gave results which were relatively close to alternative 2 . This shows that shotcrete lining takes less time than rib and lagging lining systems, which would mean less interruption of traffic in the downtown area. Based on construction duration, assumptions for the equipment list, and number of crews available, decision makers should decide which alternative would be the best solution according to cost and duration.

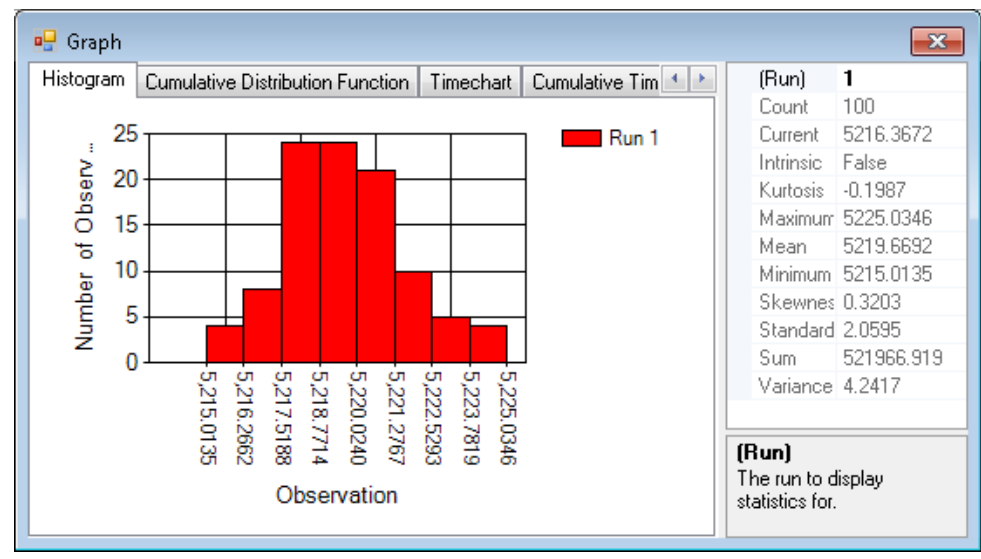

(a)

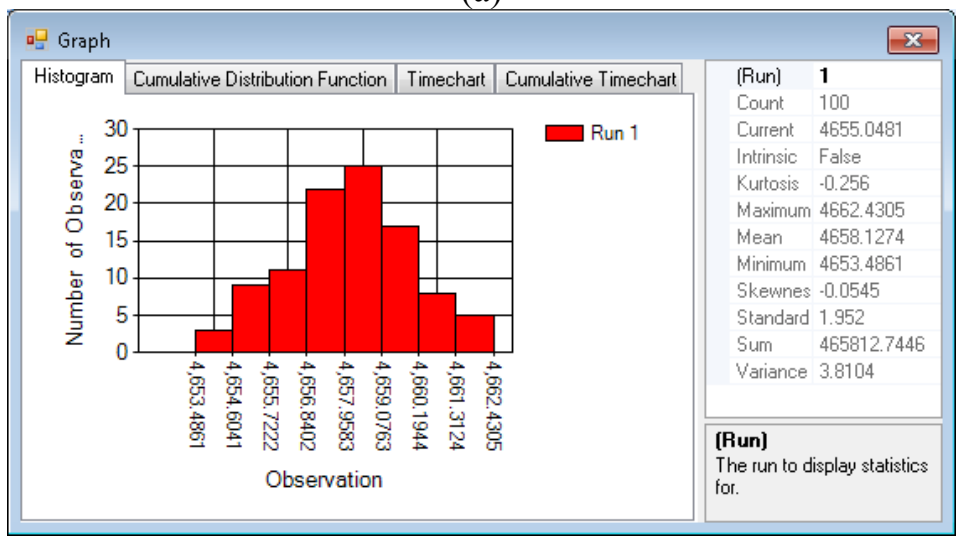

(b)

Figure 7: Cycle time of (a) north bound and (b) south bound tunnels of the project, using the shotcrete lining method 


\section{Moghani, AbouRizk, AbouRizk and Sander}

The Simphony model also provides statistical results for the cycle time of tunnel construction; since 100 runs were considered for each model, the statistical results contained a range of numbers with a minimum, maximum and mean value of the range. Figure 7 and Figure 8 illustrate the cycle time (hours) for construction of the north and south bound tunnels of the NLRT project for shotcrete lining and rib and lagging methods.

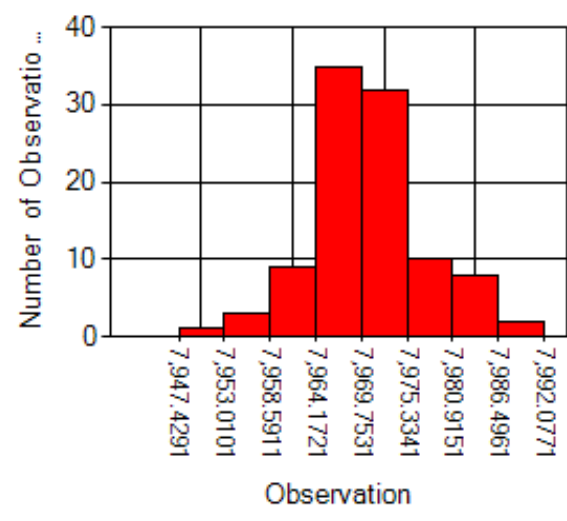

(a)

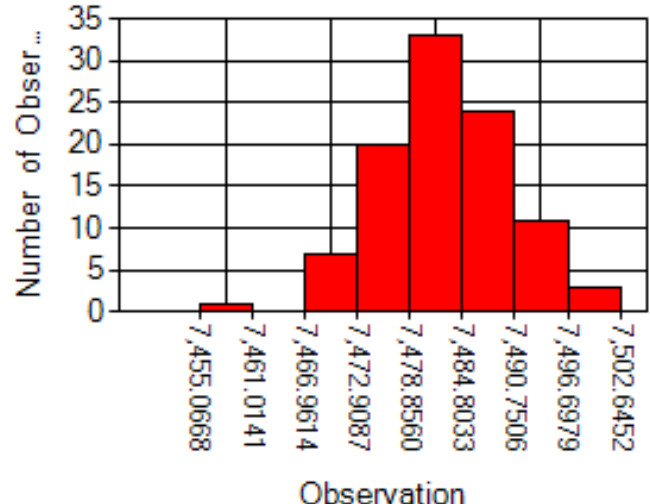

(b)

Figure 8: Cycle time of (a) north bound and (b) south bound tunnels of the project using the rib \& lagging method

The cost for the construction processes was divided into equipment cost, crew cost, and material cost. Table 5 lists the approximate cost of each method, without considering overhead cost or any costs related to final lining. The estimation shows similar values for both methods; however, the overhead cost of the project (not shown) will be much higher for the rib and lagging method because of the longer duration.

Table 5: Simulation Result - Cost estimation

\begin{tabular}{|c|c|c|c|c|c|c|c|c|}
\hline Method & $\begin{array}{l}\text { Length } \\
\text { (m) }\end{array}$ & $\begin{array}{l}\begin{array}{l}\text { Duration } \\
\text { (Weeks) }\end{array} \\
\end{array}$ & $\begin{array}{l}\text { Shift } \\
\text { (h) }\end{array}$ & Crew Cost & $\begin{array}{l}\text { Equip. } \\
\text { Cost } \\
\end{array}$ & $\begin{array}{l}\text { Material } \\
\text { Cost } \\
\end{array}$ & $\begin{array}{l}\text { North/South } \\
\text { Tunnel } \\
\text { Cost } \\
\end{array}$ & $\begin{array}{l}\text { Tunnel } \\
\text { Operation } \\
\text { Cost } \\
\end{array}$ \\
\hline $\begin{array}{l}\text { Shotcrete } \\
\text { (North) }\end{array}$ & 364 & 36 & 12 & $6,120,000$ & $2,941,120$ & $2,847,936$ & $11,909,056$ & \multirow{2}{*}{$25,067,000$} \\
\hline $\begin{array}{l}\text { Shotcrete } \\
\text { (South) }\end{array}$ & 399.8 & 40 & 12 & $6,800,000$ & $3,230,384$ & $3,128,035$ & $13,158,419$ & \\
\hline $\begin{array}{l}\text { R\&L } \\
\text { (North) }\end{array}$ & 364 & 62 & 12 & $8,370,000$ & 910,000 & 910,000 & $10,190,000$ & \multirow{2}{*}{$21,099,000$} \\
\hline $\begin{array}{l}\text { R\&L } \\
\text { (South) }\end{array}$ & 399.8 & 66 & 12 & $8,910,000$ & 999,500 & 999,500 & $10,909,000$ & \\
\hline $\begin{array}{l}\text { Shotcrete } \\
\text { (North) }\end{array}$ & 364 & 44 & 10 & $7,480,000$ & $2,948,400$ & $2,847,936$ & $13,276,336$ & \multirow{2}{*}{$28,305,000$} \\
\hline $\begin{array}{l}\text { Shotcrete } \\
\text { (South) }\end{array}$ & 399.8 & 51 & 10 & $8,670,000$ & $3,230,384$ & $3,128,035$ & $15,028,419$ & \\
\hline $\begin{array}{l}\text { R\&L } \\
\text { (North) }\end{array}$ & 364 & 75 & 10 & $10,125,000$ & 910,000 & 910,000 & $11,945,000$ & \multirow{2}{*}{$24,744,000$} \\
\hline $\begin{array}{l}\text { R\&L } \\
\text { (South) }\end{array}$ & 399.8 & 80 & 10 & $10,800,000$ & 999,500 & 999,500 & $12,799,000$ & \\
\hline
\end{tabular}




\section{Moghani, AbouRizk, AbouRizk and Sander}

Based on the time and cost analysis, the sequential excavation method with shotcrete lining seems to be the better solution. However, the final decision rests with the project managers, who will also consider availability of equipment and crew and time and cost limitations.

\section{SUMMARY AND CONCLUSION}

This paper presents an application of simulation for the selection of a construction method for a transit tunnel project. Simulation, a powerful tool in construction management, helps decision makers to choose the optimum construction scenario, considering limitations of time, money and space. This research utilizes the General Purpose Simulation template in Simphony.NET 3.5 to develop models for two construction strategies suitable for the tunnel project under study. Since the main concern of the client was the project duration, the output results were designed to demonstrate the cycle time for the tunnel construction. Four alternatives for the construction process and two scenarios for each alternative were analyzed for this project. Based on the simulation results, the sequential excavating method with shotcrete lining had the shortest duration, which means it can save time and decrease traffic disruption in the area.

\section{ACKNOWLEGEMENT}

The authors would like to thank the National Science and Engineering Research Council (NSERC) for financial support and the City of Edmonton for their extensive collaboration.

\section{REFERENCES}

Al-Bataineh, M. T. 2008. "Scenario-Based Planning for Tunneling Construction.” Doctoral dissertation, University of Alberta, Edmonton, Alberta, Canada.

Fernando, S., K. Er, Y. Mohamed, S. AbouRizk and J. Ruwanpura. 2003. "A review of simulation applications for varying demands in tunneling." In Proceedings of the Construction Research Congress; ASCE, Honolulu, Hawaii, USA, pp. 19-21.

Hajjar, D., and S. AbouRizk. 1999. "Simphony: an environment for building special purpose construction simulation tools". In Proceedings of the 1999 Winter Simulation Conference, edited by P.A. Farrington, H.B. Nembhard, D.T. Sturrock, and G.W. Evans, 998-1006.

IFL Consultants, Inc. 2008. "North LRT Extension-Downtown to NAIT, SEM Tunneling." Technical Report ILF/USA: C055 AD-0002 Rev.0.01 081015, Fairfax, Virginia, USA

Ioannou, P., and J. Martinez. 1996. "Comparison of construction alternatives using matched simulation experiments.” Journal of Construction Engineering Management, 122(3), pp. 231-241.

Marzok, M., M. Abdallah and M. El-Said. 2008. "Tunnel-sim: Decision support tool for planning tunnel construction using computer simulation." In Proceedings of the 2008 Winter Simulation Conference, edited by S. J. Mason, R. R. Hill, L. Mönch, O. Rose, T. Jefferson, J. W. Fowler, 2504-2511.

Mohamed, Y., and S. AbouRizk. 2001. "Optimizing tunneling operations using simphony's special purpose simulation library." In Proceedings of the 8th Canadian Construction Research Forum, Kananaskis, Alberta, Canada.

Ruwanpura, J. 2001. "Special purpose simulation for tunnel construction operations". Doctoral dissertation, University of Alberta, Edmonton, Alberta, Canada.

\section{AUTHOR BIOGRAPHIES}

ELMIRA MOGHANI is a Ph.D. student at the Hole School of Construction Engineering in the Department of Civil and Environmental Engineering at the University of Alberta.

HALA ABOURIZK is an M.Sc. student at the Hole School of Construction Engineering in the Department of Civil and Environmental Engineering at the University of Alberta. 
SIMAAN M. ABOURIZK holds an NSERC Senior Industrial Research Chair in Construction Engineering and Management at the Department of Civil and Environmental Engineering, University of Alberta, where he is a Professor in the Hole School of Construction Engineering. He received the ASCE Peurifoy Construction Research Award in 2008.

HEINER SANDER is CEO and Vice President at ILF Consultants, Inc. in Fairfax, Virginia. 